\title{
Article
}

\section{An unhealthy alliance}

\author{
Regan, Paul John and Ball, Elaine
}

Available at http://clok.uclan.ac.uk/15344/

Regan, Paul John and Ball, Elaine (2016) An unhealthy alliance. British Journal of Nursing, 25 (8). p. 426. ISSN 0966-0461

It is advisable to refer to the publisher's version if you intend to cite from the work.

10.12968/bjon.2016.25.8.426

For more information about UCLan's research in this area go to

http://www.uclan.ac.uk/researchgroups/ and search for <name of research Group>.

For information about Research generally at UCLan please go to http://www.uclan.ac.uk/research/

All outputs in CLoK are protected by Intellectual Property Rights law, including Copyright law. Copyright, IPR and Moral Rights for the works on this site are retained by the individual authors and/or other copyright owners. Terms and conditions for use of this material are defined in the policies page.

\section{CLoK}

Central Lancashire online Knowledge www.clok.uclan.ac.uk

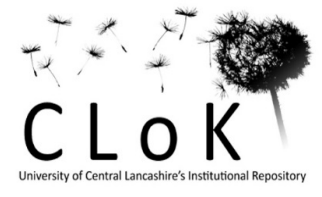


Regan, P., \& Ball, E. (2016). An unhealthy Alliance. British Journal of Nursing, 25(8), p. 426.

\section{An unhealthy alliance: Policy makers and pro-market reformers}

The National Health Service (NHS) junior doctors strike on 12/1/16 was a timely reminder of the productivity agenda impacting on working practises non-consensually (BMA, 2016). The unprecedented dispute between the department of health and the British Medical Association (BMA) is a disagreement, amongst other things about pay progression, relaxing rules on rest, working a saturday for the same pay as a week day and what constitutes a night duty (BMA, 2016). If the contractual demands are accepted then the likely effect would be the same pay for working a sunday and night duties being extended throughout nursing and the NHS. Unlike nurses however, the BMA in leading NHS market reforms with clinical commissioning groups are in a strong bargaining position.

Why the department of health were thinking along these lines may be explained by Tallis and Davis (2013) reporting a close working relationship between policy makers, the department of health, global management consultancies and think tanks advocating free market economics. The close alliance and its impact on nursing and the NHS is suggested by Tallis and Davis (2013) to be explained by the department of health's focus on increased productivity, value for money and improved data collection methods being natural perhaps when considering key researchers from management consultancies have been employed by the department and vica versa (Tallis and Davis, 2013). Why this is of concern was evident when the department of health commissioned a feasibility study by McKinsey and company to review how commissioners could improve NHS productivity 2009/10-2013/14 (DH, 2010). The recommendations to stop what they considered low value, unquantifiable clinical 
interventions (DH, 2010) had a detrimental effect on public health, community nurses and health visitors adversely affecting the timely assessment of families health needs (DH, 2011). The impact on nursing to do "more for less" was also clear in the findings of the Mid Staffordshire Trust report (2013) and the criticism of a lack of time, compassion for nurses to care and finance/ productivity prioritised by the Trust. The commissioning agenda that McKinsey reported on culminated in the Health and Social Care Act (2012) and the effects so far remain in dispute (Evans, 2008; Ham, Baird, Gregory et al., 2015). However, NHS market reforms promoting productivity have led to evidence of more service rationing, health inequalities, reduced democratic accountability and comprehensive preventative services (Krachler \& Greer, 2015).

\section{Trans-Atlantic investment partnership}

What is of more concern however are the recent secret negotiations to harmonise UK/ US trade relations with the trans-Atlantic investment partnership (TTIP), including health care. These are of concern because of the close alliance discussed so far and market reforms positioning the NHS alongside the United States (US) managed care model, with service models removed from hospitals integrated into a new primary care model (Ley and Player, 2011). TTIP ensures that the needs of trans-national companies will have priority over the UK's interests and a right to sue if profits are threatened to become a trade issue (Khan et al., 2015). For example; TTIP requires the NHS to be more competitive and open to the private sector and a "ratchet clause" prevents privatised healthcare returning to public ownership (khan et al., 2015, section 1.4.4). Even the minister in charge of negotiations has gone on record stating the NHS would benefit from further liberalisation of the markets (Khan et al., 
2015). The impact of the thirty-year NHS market reforms so far for nursing and working practice may become more significant in light of market liberalisation and TTIP.

\section{Implications for nurses}

Nurses need to be informed about market liberalisation and anti-democratic processes that promote them even further. NHS market liberalisation and TTIP depends on a passive workforce, one divided by the management narrative of productivity and value for money. Being aware of the dominant narrative can help to inform the nursing argument. Nurses need to use professional bodies and their political influence to shape the NHS away from market liberalisation.

\section{References}

British Medical Association (2016). British Medical Association summary of position as at 4 January 2016 Executive summary. London.

Department of Health (2010). Achieving world class productivity in the NHS 2009/10 2013/14: Detailing the size of the opportunity. McKinsey and Co. http://www.nhshistory.net/mckinsey\%20report.pdf.

Department of Health (2011). Health visitor implementation plan 2011-15: A call to action. https://www.gov.uk/government/uploads/system/uploads/attachment_data/file/213759/dh_12 4208.pdf.

Evans, H. (2008). NHS as state failure: Lessons from the reality of nationalised healthcare. Blackwell publishing, Oxford.

Ham, C., Baird, B., Gregory, S., Jabbal, J., Alderwick, H. (2105). The NHS under the coalition government Part one: NHS reform. The King's Fund. http://www.kingsfund.org.uk/sites/files/kf/field/field_publication_file/the-nhs-under-thecoalition-government-part-one-nhs-reform.pdf.

Khan, U., Pallot, R., Taylor, D., Kanavos, P. (2015) The transatlantic trade and investment partnership: International trade, law, health systems and public health. The London School 
of Economics and Political Science. http://www.epha.org/IMG/pdf/LSE_studyTTIP_International_Trade_Law_Health_Systems_and_Public_Health_website.pdf.

Krachler, N., Greer, I. (2015).When does marketisation lead to privatisation? Profit-making in English health services after the 2012 Health and Social Care Act. Social Science and Medicine, 124, 215-223.

Leys, C., Player, S. (2011).The plot against the NHS. Merlin press: London.

Mid Staffordshire NHS Foundation Trust Public Inquiry (2013). Report of the Mid Staffordshire NHS Foundation Trust Public Inquiry Executive summary. House of Commons. Chaired by Robert Francis, QC. Retrieved http://www.midstaffspublicinquiry.com/sites/default/files/report/Executive\%20summary.pdf.

Tallis, R., Davis, J. (2013.) NHS SOS: How the NHS was betrayed - and how we can save it. One world Publications, London. 